\title{
24. NEOGENE PALYNOLOGY OF DEEP SEA DRILLING PROJECT SITE 603 ON THE LOWER CONTINENTAL RISE, NORTHWESTERN ATLANTIC ${ }^{1}$
}

\author{
W. A. van der Kaars, Institute of Earth Sciences, Free University, and Palynological Department, \\ University of Amsterdam ${ }^{2}$
}

\begin{abstract}
The analysis of 104 core-catcher samples from Site 603 resulted in a continuous palynological record from the middle Miocene to early Pleistocene. Two palynological zones could be established (Zone 2, below $380 \mathrm{~m}$ : high Pinus, Quercus, and Carya values; Zone 1, above $380 \mathrm{~m}$ : high Pinus, and Sphagnum values). The marine pollen record was found to reflect the history of the vegetation of the eastern United States, the flora from Zone 2 indicating a warmer climate than that from Zone 1, which depicts a climatic cooling trend. The onset of Western Boundary Undercurrent deposition had no noticeable effect on the pollen distribution in the marine sediments.
\end{abstract}

\section{INTRODUCTION}

DSDP Site 603 is located on the lower continental rise $435 \mathrm{~km}$ east-southeast of Cape Hatteras (Fig. 1). Palynomorphs were examined from 54,12 , and 38 corecatcher samples from rotary-cored Holes 603 and 603B, and HPC Hole $603 \mathrm{C}$, respectively. The purpose of this preliminary study was to determine the character (qualitative/quantitative) of the palynological contents of the sediments, its potential for biostratigraphy below the $\mathrm{CCD}$, its relation with the onshore vegetation and climate, and the influence of the Western Boundary Undercurrent on the pollen distribution in the sediments.

\section{METHODS}

We prepared $10 \mathrm{~cm}^{3}$ samples from the available core-catcher material using the following standard technique. $\mathrm{HCl}$, Na-pyrophosphate, acetolysis treatment; bromoform separation $(2 \times)$, and sieving over a $7 \mu \mathrm{m}$ nylon mesh. Slides were mounted with glycerol jelly, and the cover-slips were sealed with paraffin.

Mesozoic and Paleogene forms (Aquilapollenites, Classopollis, Trudopollis, etc.) could be identified as reworked. No attempt was made to recognize reworked late Cenozoic pollen, because the use of autofluoresence as described by Gijzel (1967) would be too time-consuming, and staining techniques (Stanley, 1966) do not discriminate reworked from nonreworked Neogene pollen.

The standard pollen count is +200 angiosperm and gymnosperm pollen. Percentages of all the palynomorphs are calculated on that standard pollen sum. Most trilete spores, monolete spores, fungi spores, microforaminifers, dinoflagellates/acritarchs, and denticles were grouped and not further differentiated.

\section{RELATED STUDIES}

\section{Modern Marine Palynology}

Studies of marine sediments include work by Heusser (1983) on the pollen distribution in surficial sediments from the slope and rise of the western North Atlantic, and by Stanley (1966) on the palynology of Quaternary

\footnotetext{
1 van Hinte, J. E., Wise, S. W., Jr., et al., Init. Repts. DSDP, 93: Washington (U.S. Govt, Printing Office).

2 Present address: Palynological Department, Hugo de Vries Laboratory, University of Amsterdam, 1018 BX Amsterdam, The Netherlands.
}

sediments from the continental shelf and ocean basin of the northwestern Atlantic. These sediments off the eastern coast of the United States contain high values of Pinus (pine) pollen (up to $90 \%$ ), with less Quercus (oak) $(10-20 \%)$ and other pollen types in very small numbers only. In general, the palynology of the marine sediments is a reflection of the vegetation of the adjacent land area, with a seaward increase in the relative frequency of Pinus pollen, and a seaward decrease in variety of pollen types.

\section{Recent Onshore Pollen Distribution}

According to Davis and Webb (1975), the southeastern North American forests are characterized by high percentages of Pinus (30-70\%), Quercus $(15-30 \%)$ and southeastern tree pollen: Taxodium (cypress), Liquidambar (sweet gum), Nyssa (black gum), and Liriodendron (tulip tree) (5-45\%). Other common species are Carya (hickory), Betula (birch), and Ulmus (elm) (up to 5\%). Locally important are, amongst others, Acer (maple), Alnus (alder), Corylus (hazel), and Juglans (walnut).

\section{Late Tertiary Floras}

Palynological studies by Traverse (1955) on the Brandon lignite, Vermont (upper Oligocene or lower Miocene), and by Rachele (1976) on the Legler lignite, New Jersey, give some information on the late Tertiary vegetation of the eastern United States. Apart from local swamp elements, one of the numerically important species is Quercus (mostly 30-70\%); Pinus occurs in larger numbers only in the Legler lignite (up to $20 \%$ ). The dominant vegetation of the Brandon lignite, excluding the swamp elements, contains Quercus, Engelhardtia, Car$y a$, and Ulmaceae, that of the Legler lignite is Quercus, Pinus, and Carya.

\section{RESULTS}

From the 104 samples analyzed, three (603B-14,CC, $603 \mathrm{~B}-15, \mathrm{CC}$, and 603B-16,CC) proved to be barren of palynomorphs. Two samples (603-10,CC, and 603-15,CC) contained less than the standard +200 pollen count, but 


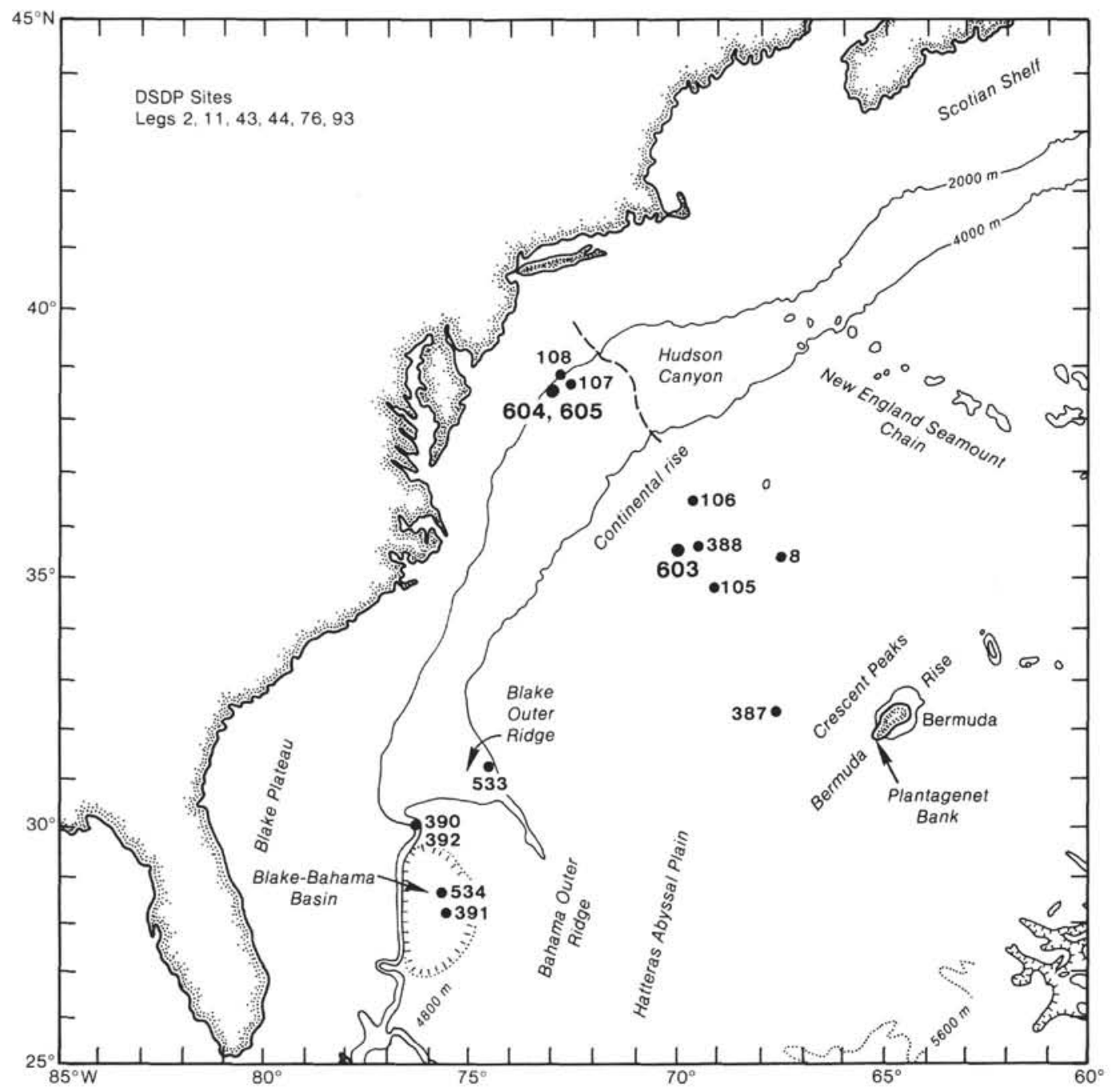

Figure 1. Location of Site 603.

more than 100 pollen; they were used in Figure $2 \mathrm{~A}$. In all other samples the standard pollen sum was reached. The relative percentage curves of 25 groups of palynomorphs are presented in Figure 2, in addition to these curves, infrequently occurring taxa are shown where they were encountered, with the percentage.

The numerically most important pollen taxa are Pinus (21-92\%) and Quercus (4-58\%), which together account for $70-96 \%$ of the pollen sum. The other pollen taxa generally each represent less than $2 \%$ of the pollen sum; only Carya, Gramineae, and Compositae reach 5-7\%. The curves of the other palynomorphs (spores, dinoflagellates/acritarchs, etc.) do reach higher values.

Two zones could be established: Zone 1, above $380 \mathrm{~m}$ sub-bottom depth, is characterized by higher values of Pinus and Sphagnum (peat moss) and lower values of Quercus and Carya than is Zone 2, below $380 \mathrm{~m}$ subbottom depth.

Photographs of more frequently occurring unidentified palynomorphs are presented in Plate 1. All material is filed at the micropaleontological collection of the Institute of Earth Sciences, Free University of Amsterdam.

\section{DISCUSSION}

The rather small number of taxa and their often infrequent occurrence proved to be an obstacle in establishing a qualitative palynostratigraphy. We could establish the upper range of Podocarpus (middle-late Miocene, $600 \mathrm{~m}$ in Fig. 2B), Engelhardtia (middle Pliocene, $210 \mathrm{~m}$ in Fig. 2A and Pterocarya (middle Pliocene, $190 \mathrm{~m}$ in Fig. 2A). Above these limits, the taxa occur only sporadically and are probably reworked or transported over long distances. Podocarpus, Engelhardtia, and Pterocarya no longer exist in the eastern United States: Podocarpus and Engelhardtia, today, do not occur north of Mexico and the Caribbean islands, and Pterocarya is confined to Asia (Rachele, 1976).

The onset of contourite deposition from the Western Boundary Undercurrent at around $750 \mathrm{~m}$ in Figure 2B (see Site 603 chapter, this volume) is not reflected in the pollen distribution. There was no influx of marine-transported pollen from further north (pollen was still relatively locally derived), and no increase in the amount of reworked pollen. 
In general the results in Figure 2 agree with the palynology of the modern marine sediments. The only marked difference is the Pinus/Quercus ratio below $380 \mathrm{~m}$ (Zone 2) - about $55 / 45$ as compared with about $90 / 10$ in Recent sediments, perhaps indicating a greater abundance of Quercus in the onshore vegetation than at present. The dominant vegetation below $380 \mathrm{~m}$ as reflected by Figure 2B, contained Quercus, Pinus and Carya, with Ilex, Corylus, Juglans, Engelhardtia, Pterocarya, Liquidambar, Gramineae, and Compositae as other important elements. This clearly resembles the Legler flora (Rachele, 1976), especially if the swamp elements from that flora are omitted. The similarity with the older Brandon flora (Traverse, 1955) is far less; Pinus, for example, is virtually absent from the flora.

We can therefore conclude that, in general, the history of the vegetation of the eastern United States is reflected by the marine pollen record in the sediments of the lower continental rise. The flora from Zone 2, below $380 \mathrm{~m}$, suggest a warm temperate climate. In Zone 1, above $380 \mathrm{~m}$, the Pinus/Quercus ratio reaches values found in modern marine sediments in this area $(90 / 10)$ (Heusser, 1983). This change may represent a large-scale climatic cooling trend, as is further indicated by the larger numbers of Spaghnum, the lower number of Car$y a$, and the absence of Juglans, Engelhardtia, Liquidambar, and Pterocarya from most of the upper part of Zone 1 (Fig. 2A). Two possible Pleistocene glaciations may be reflected in Figure 2A at $80 \mathrm{~m}$ and from 50 to 60 $\mathrm{m}$, which show very high Pinus and very low Quercus values, and where Carya, Juglans, Engelhardtia, Pterocarya, and Liquidambar are absent. The amount of reworked pollen remains the same through the section, and there is no noticeable difference between turbidites and turbidite-fed contourites.

\section{CONCLUSIONS}

1. The amount of palynomorphs in the studied sediments is adequate for future, detailed pollen analysis.

2. The onset of deposition from the Western Boundary Undercurrent is not recorded in the palynology of the sediments.

3. A detailed qualitative palynostratigraphy could not be established because of the stable vertical pollen distribution and the selectivity of marine pollen transport.

4. A more detailed quantitative palynostratigraphy, and consequently a more detailed investigation of the climatic changes is feasible, if larger samples are available, Pinus and Quercus are omitted from the standard pollen count (that is, if more pollen is counted), and a closer sample spacing is used. Our present results, based on widely spaced samples, suggest a large-scale climatic cooling trend.

\section{ACKNOWLEDGMENTS}

The author wishes to express his gratitude to E. Beglinger, Th. van der Hammen, J. E. van Hinte, and T. A. Wijmstra for their help and stimulation during the course of this investigation, and to the Deep Sea Drilling Project and Leg 93 shipboard scientists and technicians for collecting the material and making it available for study.

\section{REFERENCES}

Davis, R. B., and Webb, T., 1975. The contemporary distribution of pollen in eastern North America: a comparison with the vegetation. Quat. Res., 5:395-434.

Gijzel, P. van, 1967. Autofluoresence of fossil pollen and spores with special reference to age determination and coalification. Leidse Geol. Med., 40:264-317.

Heusser, L. E., 1983. Pollen distribution in the bottom sediments of the western North Atlantic Ocean. Mar. Micropaleontol., 8:77-88.

Rachele, L. D., 1976. Palynology of the Legler lignite: a deposit in the Tertiary Cohansey Formation of New Jersey, U. S. A. Rev. Palaeobot. Palynol., 22:225-252.

Stanley, E. A., 1966. The application of palynology to oceanography with reference to the northwestern Atlantic. Deep-Sea. Res., 13: 921-939.

Traverse, A., 1955. Pollen Analysis of the Brandon Lignite of Vermont. U.S. Dept. Int. Bur. Mines Rep. Invest., 5151.

Date of Initial Receipt: 27 March 1985

Date of Acceptance: 31 January 1986

\section{APPENDIX}

Palynology of Some Samples Around the Cretaceous/Tertiary Boundary, Northwest Atlantic Sites 603 and $\mathbf{6 0 5}$

Eight core-catcher samples from DSDP Hole 605 and four from Hole 603B were processed for palynological analysis, using the following method: $10 \mathrm{~cm}^{3}$ crushed sample was boiled in $\pm 20 \% \mathrm{HCl}$ (if required), followed by boiling in $10 \%$ Na-pyrophosphate, acetolysis, and bromoform separation.

The four samples from Hole 603B proved to be completely barren of palynomorphs (the heavy-liquid separation produced no organic residue at all). The eight samples from 605 contained "coal" fragments, plant debris, and some palynomorphs (see appendix Table 1). The number of palynomorphs was too small for meaningful pollen analysis, but additional sampling may yield age-diagnostic forms and sufficient numbers of dinoflagellates/acritarchs.

Table 1. Palynological results.

\begin{tabular}{|c|c|c|}
\hline $\begin{array}{l}\text { Core-catcher } \\
\text { sample }\end{array}$ & $\begin{array}{l}\text { Sub-bottom } \\
\text { depth of core } \\
\text { (m) }\end{array}$ & $\begin{array}{l}\text { Pollen } \\
\text { content }\end{array}$ \\
\hline \multicolumn{3}{|l|}{ Hole 603B } \\
\hline $21, \mathrm{CC}$ & $1011.6-1020.6$ & Barren \\
\hline $22, \mathrm{CC}$ & $1020.6-1029.6$ & Barren \\
\hline $23, \mathrm{CC}$ & $1029.6-1038.6$ & Barren \\
\hline $24, \mathrm{CC}$ & $1038.6-1047.6$ & Barren \\
\hline \multicolumn{3}{|l|}{ Hole 605} \\
\hline $57, \mathrm{CC}$ & $672.7-682.3$ & 5 pollen grains ${ }^{a}$ \\
\hline $60, \mathrm{CC}$ & $701.5-711.1$ & 3 pollen grains ${ }^{a}$ \\
\hline $66, \mathrm{CC}$ & $759.1-768.7$ & 11 pollen grains $^{\mathrm{a}}$ \\
\hline $68, \mathrm{CC}$ & $778.3-787.9$ & No palynomorphs \\
\hline $69, \mathrm{CC}$ & $787.9-797.5$ & 2 pollen grains ${ }^{\mathrm{a}}$ \\
\hline $70, \mathrm{CC}$ (top) & $797.5-807.1$ & 18 pollen grains $^{\mathrm{a}}$ \\
\hline $70, \mathrm{CC}$ (bottom) & $797.5-807.1$ & 4 pollen grains ${ }^{\mathrm{a}}$ \\
\hline $71, \mathrm{CC}$ & $807.1-816.7$ & Some dinoflagellates/acritarchs \\
\hline
\end{tabular}




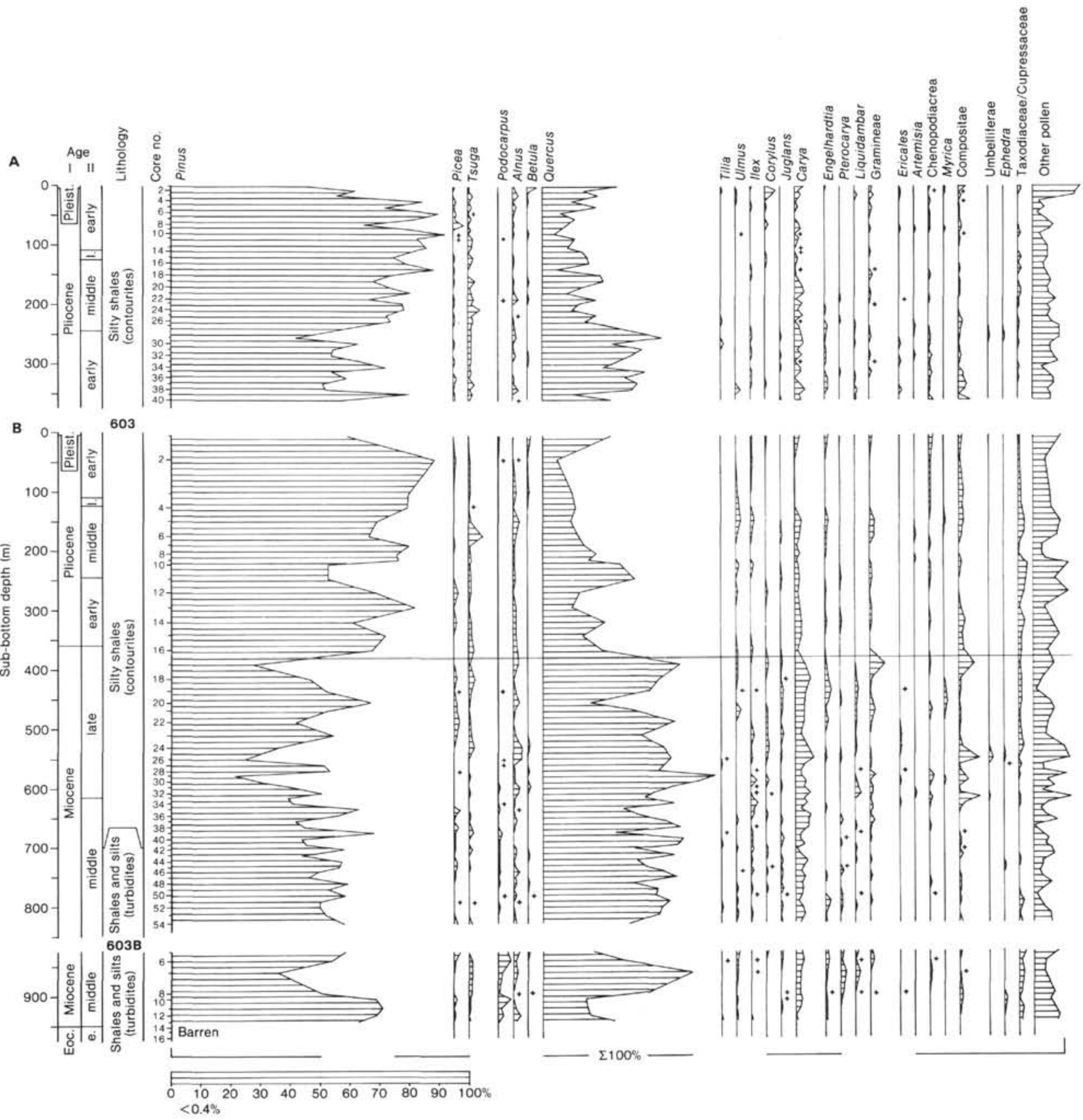

Figure 2. Distribution of palynomorphs from core-catcher samples in (A) HPC Hole 603C and (B) rotary-cored Holes 603 and $603 \mathrm{~B}$. Values for infrequently occurring pollen in percentages. Alternate time scales are based on dates for the Pliocene/Pleistocene boundary of (I) $1.6 \mathrm{Ma}$ and (II) $2.6 \mathrm{Ma}$, respectively. 


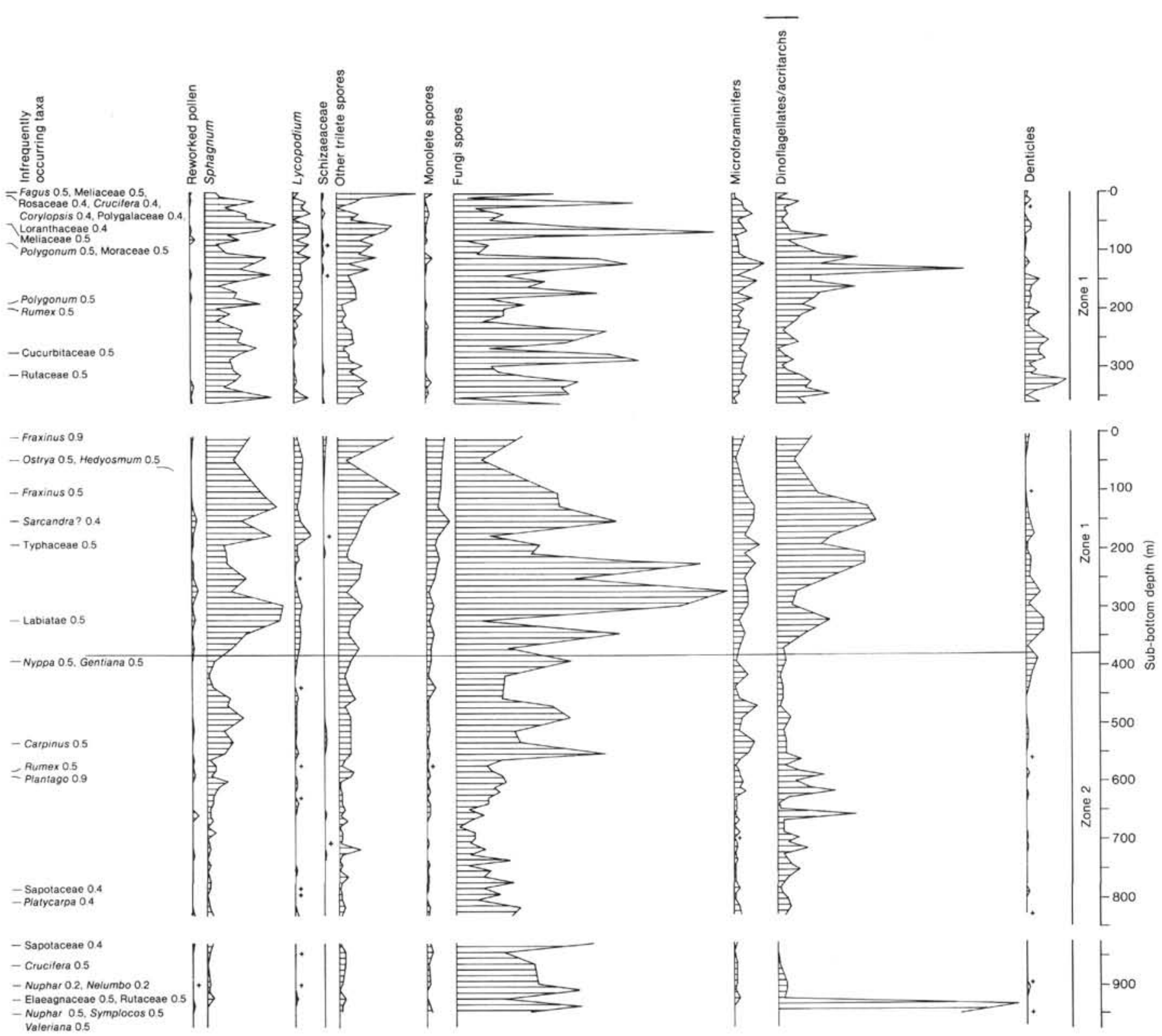

Figure 2 (continued). 


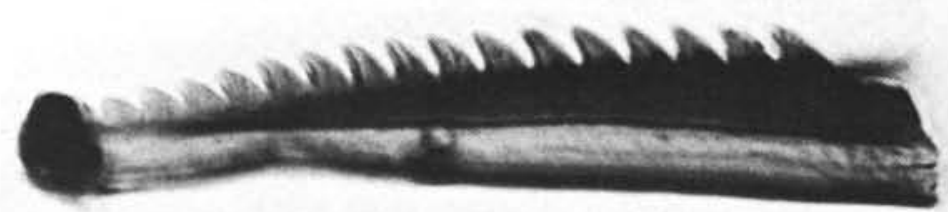

1

3

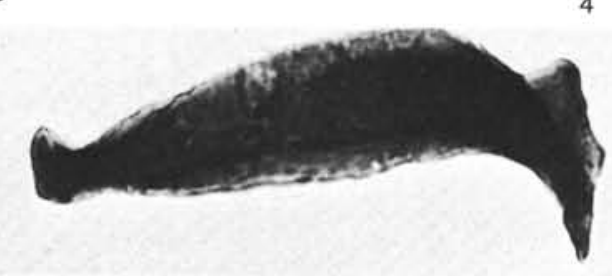

5

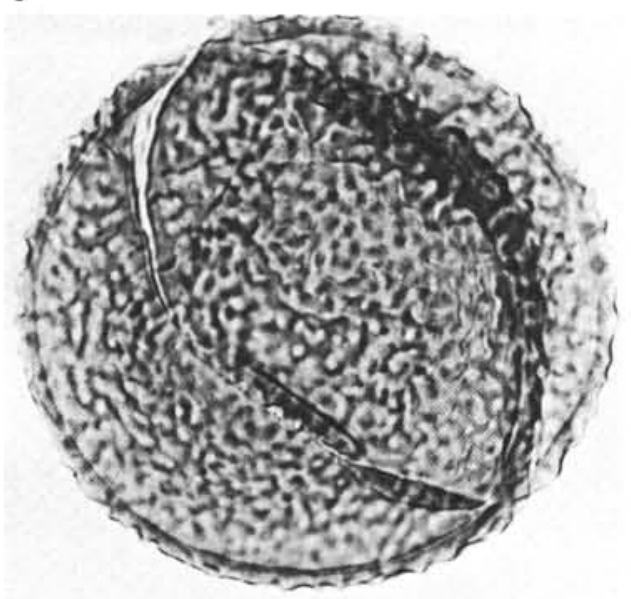

7

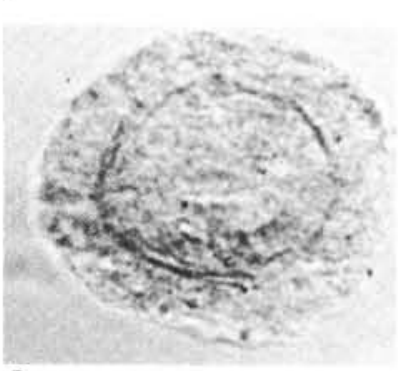

9

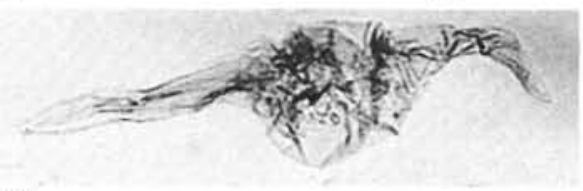

4

6

8

11
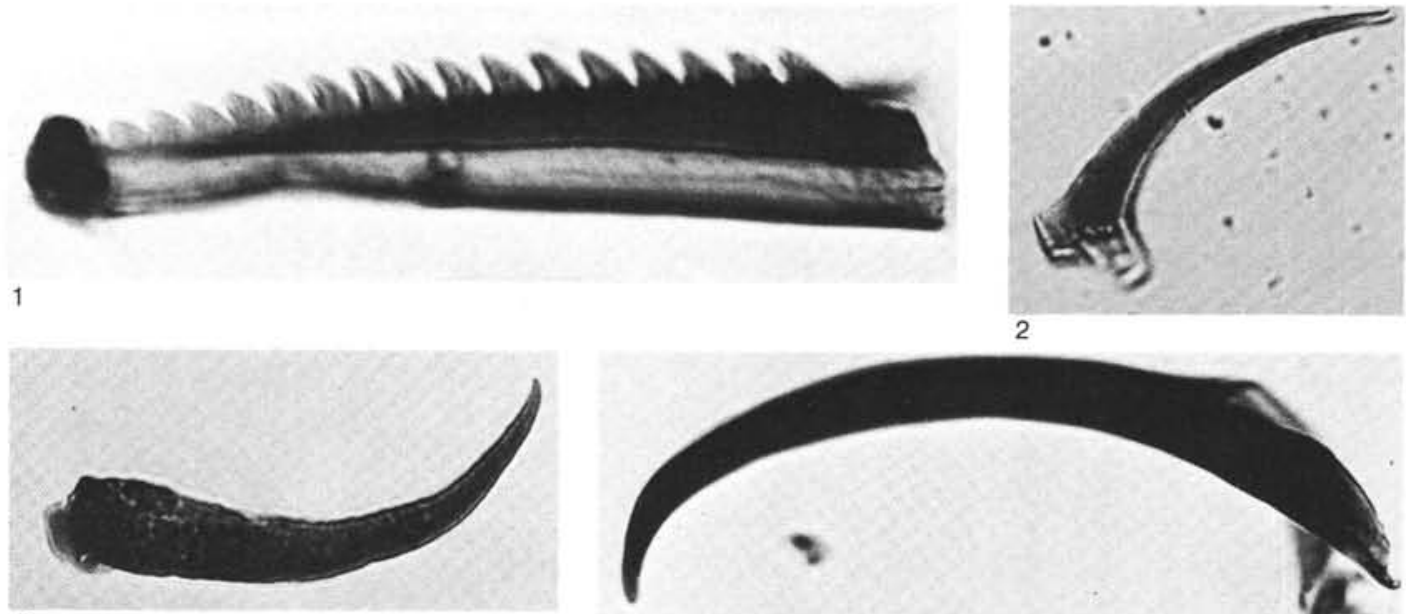

2
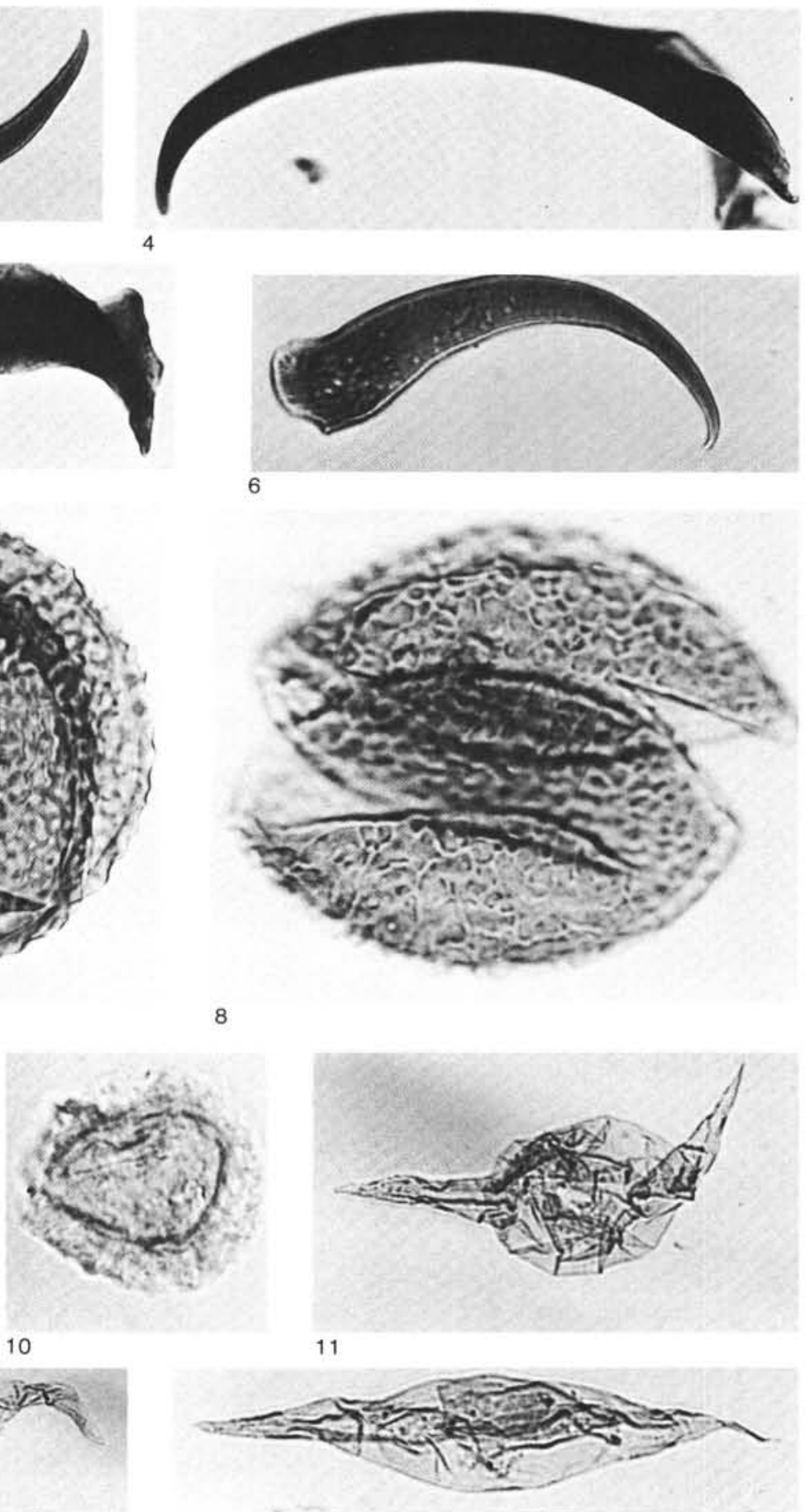

13

Plate 1. Unidentified palynomorphs. (Figs. 1, 9, 10, $\simeq 1600 \times$; Figs. 2-8, 11-13, $\simeq 650 \times$.) 1. Denticle, Sample 603C-4,CC. 2, 3. Denticles, Sample 603C-24,CC. 4. Denticle, Sample 603C-4,CC. 5. Denticle, Sample 603C-34,CC. 6. Denticle, Sample 603C-24,CC. 7, 8. Incertae sedis type B, Sample 603-37,CC. 9, 10. Incertae sedis type E/F, Sample 603B-10,CC. 11-13. cf. Leiofusia, Sample 603B-13,CC. 